\title{
Registering People in a Changing Society - the Case of Finland
}

\author{
By KARI PITKÄNEN \\ University of Helsinki \\ Department of Economic and Social History
}

\section{Introduction}

As Finland was part of the Swedish Kingdom, her population statistics also originate from the middle of the 18 th century. The statistics were based on the information provided by the church registers. The first uniform instructions for keeping church registers were given to the Swedish parish clergy in the Church Law of 1686 . The law obliged the clergy to keep registers of births and baptisms, marriages, deaths and burials, in- and out-migrants and in addition to keep communion books (rippikirjat), which were to include certain information about all parishioners (or at least of those over approximately 15 years of age). Although in some parishes these registers had already been kept for some decades ${ }^{1}$ it seems that in many parishes they were not begun to be kept until some time after the Church Law was published (Pitkänen 1976, 1617). ${ }^{2}$ At this time the purpose of these registers was purely »ecclesiastical». They registered religious acts (baptisms, marriages and burials), recorded the parishioners' knowledge of Christianity and their participation in Communion.

In the first part of the 18th century the Swedish government realized that these parish registers could act - at least after some improvements - as the basic material for population statistics covering the entire kingdom. To collect this statistical information of the population, a system called »Tabellverket» was founded in 1748 . The same year the parish clergy was ordered by a Royal letter to improve - if necessary - their parish registers in order to meet the demands of population statistics (Lundell 1913, 17-19; Hjelt 1900, 94-96). In the beginning of 1750 each parish rector had to fill two separate statistical forms - called population and population change ("mortality") tables - for the preceding year 1749. On the population form the parish rectors had to give information concerning the amount of parishioners and their composition by

1 These registers are not, however, as old as one sees widely presented in literature (see Lempiäinen 1965, 198-199).

2 The registers of in- and out-migrants were, however, quite rare until the first half of the 19th century. 
age, sex, civil and occupational status. On the latter form they had to give information concerning births, deaths and marriages.

The number of Finland's population was thus not obtained by a census in the modern sense, instead the censuses were merely inventories made on the basis of communion books - or the parish main books - as these registers were officially called later on. This system prevailed until 1950, when the first direct census was taken. ${ }^{3}$

In several connections it has been repeated that the inventory of the main books ${ }^{4}$ gave a good picture of the size of the population in Finland until the end of the 19th century, i.e., that the parish main books fairly accurately contained the actual population living in the parishes, and thus also the actual population of Finland. It has been thought that the beginning of industrial and urbanizational development caused this situation to change in the late 19th century. The train of thought in this affirmation has been the following. There was a significant increase in internal migration, because people began to move from the countryside to the cities and to industrial centers in the countryside. Emigration also increased immensely. The increase in migration and emigration raised a problem with population registration, for those who emigrated abroad were retained in the parish main books and similarly many of those who moved within the country did not transfer their »books» ${ }^{5}$ to the new parish but instead remained members of the old home parishes. Therefore the parish main books no longer gave a true picture of the people actually living within the parishes and the population figures reached on the basis of these books did not give the actual population living in Finland as a whole (see e.g. SVT VI: 45, 22 and Hyppölä et al. 1949, 14-16).

There is no doubt that the population registered in the parish main books deviated significantly for the first time from the actual population of the parishes in the latter half of the 19 th century. However, the causal relationship described above is not only incomplete but it is also, in many respects, totally deceptive. In the following I will try to outline the development which led to the situation described above and the consequences which it had on the official population registration and statisties in Finland at the turn of the 20th century:

3 In the larger cities direct censuses were taken already from 1870 onwards.

4 These inventories were made on a yearly basis in $1749-51$, every third year in $1754-75$, every fifth year in $1775-1880$ and every tenth year in $1880-1940$.

5 Those who moved from one parish to another should have obtained a certificate from their old parish. This migrant's certificate included his or her personal history: name, age, civil status, reputation, whether confirmed or not, etc. When a person took this certificate to the rector of the parish into which he had moved, he became a member of this parish. 


\section{From an open to a closed population registration system}

Thus, it has been thought that the problems in population registration were caused by an increase in migration and the fact that the migrants often were retained in the main books of their old home parishes. But the fact is, however, that neither internal nor external migration were new phenomena in the late 19 th century. One cannot even claim that internal migration increased at this time, because it was already very lively in the 18th century (see Rosenberg 1967, 215-216; Pitkänen 1976, 136). It was also true during the 18th century that many migrants did not move their »books» to their new home parish or that they did so only after some delay (Pitkänen 1976, 133-134). In addition, emigration to Russia, especially to St. Petersburg, was significant already in the first half on the 19th century (Engman 1978, 165-167).

The reason why the parish main books in the middle of the 19 th century still contained relatively well the actual population of the parishes, despite the facts described above, was the result of two intertwined factors. The first was the different nature of the migration. Most migrants were laborers working in agriculture and when a farm hand or a servant girl (employed on a yearly basis) changed his place of employment, he also changed his place of residence. In the same way also the agricultural laborers who were engaged in temporary work changed their place of residence frequently. This migration was a net of very short distance changes in one's place of residence. A farm hand moved to a neighboring farm or village or in some cases to the neighboring parish. Because only a small part of all these moves crossed the parish border, the majority of the earlier migration was not entered in the registers of migrants. The net result of this migration remained fairly insignificant (Pitkänen 1976, 139-141).

Thus there is no ground for a claim that the volume of internal migration would have increased towards the end of the 19th century. Instead, one can say that the nature of migration changed significantly towards the end of the 19 th century. Due to the increase in the landless agricultural population in the 19th century and changes in agriculture, it became more difficult to find work in agriculture (see e.g. Soininen 1976, 41-44, 393-394 and 398). On the other hand, the growing industry and service sector needed labor force. Most of the industry was located in the cities and in some industrial centers in the countryside and the migration flow began to be directed in increasing numbers towards these centers. Therefore internal migration increasingly began to be longdistance migration, which gradually changed the regional distribution of the population. In addition, many people also sought a better future abroad.

This change in the nature of migration cannot, however, alone explain why the problems in population registration did not begin until the latter part of the 19th century. There had always been some long-distance migration, especially between the cities (Pitkänen 1979), and emigration also, as mentioned 
above. Similarly, people did not always transfer their »books» - at least not immediately - when they moved. The reason why these factors had no effect was that in the 18th and in the first half of the 19th century the parish main books were generally kept according to the principle of "open registration». It is not easy to interpret the entries in these main books, but when one examines them one can clearly notice in many cases that if a person either emigrated abroad or moved within the country without transferring his »books", he was nonetheless struck off the parish main books of his old parish and marked in the books of the new home parish.

The system of »open registration» was also supported by the instructions given to the parish clergy. In the instructions written on the first population table form (used in 1749-1772) the parish clergy was told to include in the table those parishioners "who actually live in the parish or have stayed there for most of the year». This principle was repeated again at the beginning of the 19th century when the clergy was obliged to check at the slukukinkerit» (a general examination in reading held yearly in rural parishes) that their parish main books contained only those who actually were living in the parishes. ${ }^{6}$

The open registration system served the government's purposes in finding out the true size of the population, but the system was also natural considering the secclesiastical» function of the records. The parish main books were an important record, in which the clergy entered information concerning an individual's participation at communion, ability to read, etc. The parish rector was responsible for the people living under his supervision, i.e., within his parish. In other words, it is incorrect to consider the parish main books of the 18th century or the beginning of the 19 th century as a kind of »official population register". They were ecclesiastical registers, which in addition were used to obtain certain demographic information on the population.

By observing the parish main books one can see that the shift from the system of wopen registration" towards "closed registration" had already begun in the first half of the 19 th century, for it can be seen already then that in some parishes the people who had moved from the parish without taking the migrant's certificate had remained within the parish main books. ${ }^{7}$ This change was not completed, however, until the latter half of the 19th century.

It is not possible to fully explain what the reasons were behind this change. It was not caused by any direct legislative act, which explains why this change was slow and took place at different times in different parishes. In fact, at the beginning it was even in contradiction with the legislation of the time. But, on the other hand, it was indirectly supported by some proclamations and there

6 See Hornborg 1872, Kyrkoskrifne 13.3.1805 and the circular letter of the diocese of Turku in 10.10.1804.

7 See e.g. the parish main books of Espoo and Mäntsälä (the church archives of Espoo and Mäntsälä in the National Archives of Finland) and Pitkänen 1976, 45. 
were also several practical reasons which made this change necessary.

After Finland was annexed as an autonomous state to the Russian Empire, it took almost a hundred years before legislation clearly brought into effect the system of closed population registration in the parish main books. Earlier these books were linked with the personal taxation lists, the poll-tax registers (henkikirjat). The latter were, in fact, more like an official population register. When the system of poor relief was developed it was important to find out a persons's legal place of residence, i.e., what parish was responsible for his support. This location was indicated as the parish in which the person was registered on the poll-tax lists. ${ }^{8}$

Several Imperial proclamations ordered that a person be entered in the polltax registers in that place where he had »his dwelling and home» (asuntonsa ja kotonsa). ${ }^{9}$ The wording is not very clear in legal terms, as Talas has shown $(1905,101-102)$. In any case, one can say that in practice this refers to the place where a person's permanent dwelling was and where his center of economic and other activities was. Most clearly this was expressed in the Proclamation of 1865 (12 §).

The role of the parish main books was not totally unambiguous in this system. In 1865 it was ordered that a person had to be entered in both the poll-tax lists and the parish main books in that parish where he had his "dwelling and home». The same idea was also presented in the Proclamation of 1892. In the Proclamation of 1878 the idea was transformed in such a way that the place of residence was, in practice, made dependent on the place where a person was registered in the parish main books (Talas 1905, 102-103). In any case the legislation aimed at an ideal situation in which a person was registered in both registers in that place where he actually permanently lived.

During the last decade of the 19th century, however, the legislation had to face the fact in a very short period that this ideal situation could not be reached. The Proclamation of 1894 separated the two kinds of registers and after this the parish main books were meant to be used only as an aid in deciding a person's true place of residence. The Imperial Proclamation of August 14 in 1898 finally legalized the system of closed registration in the parish main books by declaring that it was illegal to exclude a person from the parish main books before it was known that he was entered in the parish books of some other parish, which, in turn, was possible only by transferring the individual's personal history through a migrant's certificate (see Talas 1905, 104).

This change in the legislation actually only confirmed what was already true in practice. It is not possible to find out all the reasons which changed

8 See the Royal Proclamation of December 6, 1788 and the Imperial Proclamation of September 9, 1817.

9 See Imperial Proclamations of February 20, 1865, December 9, 1878, September 13, 1892 and April 10, 1894. 
the practice in the 19 th century, but one can ascertain some of them. The population of Finland grew very rapidly during the 18th and 19th centuries and the often mentioned lack of labor force in the 18th century quickly changed into a surplus supply of labor force. People had to leave their home parishes more often than before to find work. Many probably had no intention of staying permanently in another district, but instead planned to return to their home parish when things became better. These persons could take along a certificate containing their personal history in order to seek work in some other place (often called »certificate of reputation»). These certificates were meant to be used only during a temporary absence from one's parish. ${ }^{10}$

Thus it was quite natural that these persons were left in the parish main books, because by taking only a certificate of reputation they had explicitly expressed that they had no intention of moving permanently to another parish - for the time being at least. But the fact was that many stayed in another parish for a long period and then possibly applied for a proper migrant's certificate. A time lapse between the true date of migration and application for a migrant's certificate was in fact very common. Because the numbers of those staying outside the parish grew and because there was always the possibility of their applying for a migrant's certificate, it is natural that the parish clergy no longer excluded people from the main books even if they had left the parish without taking any kind of certificate. There was also the possibility that the administrative officials would request information concerning persons staying outside the parish. Although the parish main books may not have been conclusive concerning one's place of residence, they gradually became important as a conclusive source concerning an individual's personal history. Such information was naturally not to be destroyed before it was transferred through a migrant's certificate to the main books of some other parish.

Other reasons, which no doubt led towards the system of »closed registration", were the proclamations concerning those who had emigrated to Russia. It is true that already in the beginning of the 19th century the "Tabell commission" had given instructions that persons who had traveled abroad should not be excluded from the main books as long as they were known to be alive.11 But in spite of these instructions these stravelers» were usually excluded from the main books, also including persons who had emigrated to Russia. Strictly speaking after Finland was annexed to Russia, the latter were not emigrants who had moved to a foreign country but nonetheless they were still excluded from the registers. ${ }^{12}$

The Imperial Proclamations of March 30, 1848 and May 10, 1850 declared that persons and their offspring who had moved to Russia were bound to their old home parishes in Finland and were to be left in the main books of their

10 Later on a »certificate for seeking work» was given by the secular authorities.

11 See the circular letter of the diocese of Turku in October 10, 1804.

12 There seemed to be a few exceptions (see Engman 1976, 111). 
old parish. It took some time, however, before this new requirement was adopted by the parish clergy (see Engman 1976, 113 and Pitkänen 1976, 46). The same principle was also applied to those who migrated abroad (outside Finland and Russia). They remained members of their old parishes as long as they were Finnish citizens.

Another factor also leading towards the system of closed registration were the proclamations declaring that people who went to build the Saimaa canal were to be left in the parish main books of their home parishes. In addition, those who went to build the railways during the latter half of the 19th century were left the choice of remaining members of their home parishes (Pitkänen 1976, 46).

Thus the change in the system of registration was of fundamental importance considering the reasons why the difference between the true and "legal» population started to grow during the latter half of the 19 th century. Also the change in the nature of internal migration was connected with the change in the registration system and e.g. attributed to the extent of the difference between the true and »legal» population in different parishes.

\section{The resident population of Finland and the situation in 1890}

What then were the consequences of the change in the registration system to the reliability of the parish main book inventories. In this connection only the population figures from around the turn of the 20 th century are taken into consideration.

During the latter half of the 19th century it was noticed that the reliability of the parish main book inventories had decreased and the first action to be taken was that direct censuses were taken in the largest cities from 1870 onwards. Areas included in these censuses often were not limited to the city but also included the suburbs outside the borders of the city. The official population figures from Finland were, however, still obtained by inventories of the parish main books.

Because of emigration the figures obtained from the inventories were too high and because of this the parish clergy had to make a distinction on the population tables from 1910 onwards between those who were "present" (living in the parish) and those who were »absent» (living outside the parish). Afterwards a new series of population figures, the so called "resident population»13 has been counted retroactively for Finland. This series is used in official statistics and has been published in the Statistical Yearbook of Finland since 1949.

The basic presumption when the resident population was counted was that before 1890 relatively little emigration abroad had existed and that the popu-

13 Finnish citizens who were permanently living in Finland. 
lation figures obtained by the inventories of the main books corresponded rather well with the size of the true resident population as late as the inventory of December 31, 1890. The resident population of 1900 was counted from the population of 1890 by adding to it the numbers of births and return migrants and by subtracting from it the numbers of deaths and emigrants. The resident population of the years 1910-1940 was counted with the help of the information of the "present» and »absent» population obtained from the parish main book inventories (see Hyppölä et al., p. 16). In addition, the poll-tax registers were also used to obtain population figures for Finland. Already in the late 19th century the role of the poll-tax registers as population registers was emphasized, and in 1925, when the personal poll-tax was abolished, the function of taxation was totally removed from these registers. ${ }^{\mathbf{1 4}}$

It seems, however, that even the resident population overestimates the actual population living in Finland. First of all, the basic presumption concerning emigration is incorrect. It is true that the emigration presented in the official emigration statistics reached its peak after 1890, but first of all this »emigration» included only emigration overseas, i.e., mainly to America. There was, however, emigration elsewhere too, even long before the 1890's. Sweden had been a traditional destination for emigrants. From the modern point of view, those who moved to Russia were also emigrants. According to the census taken in Russia in 1881, when the Finnish population of St. Petersburg reached its peak, over 24000 Finns lived in the city itself and in the nearby suburbs (Engman 1978, 164). On the other hand, the lists of the Finnish Passport Office in St. Petersburg, which registered those Finns who were in Russia on a passport, contained about 40000 Finns in the late 1800's (Engman 1978 a, 48).

In addition, emigration overseas had also gained significant proportions before the beginning of the 1890's. From Kero's estimates one can calculate that before the end of the year 1890 about 50000 persons had emigrated from Finland overseas (Kero 1974, 24-34).

It is difficult to give even a crude estimate of the number of emigrants who had been kept in the parish main books in 1890, because the system of closed population registration never became totally stringent (see Pitkänen 1976, 272). ${ }^{15}$

14 This abundance of population figures may be very misleading to non-experts and cause annoying situations when one looks for population figures in order to relate some phenomenon to the population of Finland. A recent example is an article by Hjerppe and Pihkala $(1977,65)$ in which they have counted the GDP per capita in Finland by using as population figures for 1900 the resident population, but for the year 1913 the total population obtained directly from the parish main books (6.4. per cent higher than the resident population).

15 Although the system of closed registration "failed" to some extent even in the beginning of the 20th century (see Väestötilastokomitean mietintö 1923:7, 19), the amount of these sillegally» crossed-off persons cannot be exaggerated. The amount of natural increase is somewhat underestimated in the official statistics, but in any case one must notice that in $1880-1930$ the population increase shown by the parish main book inventories (total population) always exceeded the natural increase. 
In addition, it would be essential to know the amount of return migration. One can, however, estimate that the sexcess» population in the parish main books in 1890 was higher than 50000 but possibly less than 100000 persons. ${ }^{16}$

\section{Resident population on December 31, 1900}

Even if we knew the exact amount of resident population in 1890 we still would not be able to calculate the resident population in 1900 the way it is done (see above), because we do not know the exact population change figures. ${ }^{17} \mathrm{We}$, however, have a way to estimate the amount of the resident population in 1900 by using other, independent, information, although the estimate is by no means exact. Thus we can get an idea as to what extent the size of the "official» resident population presented in the official statistics is erroneous. According to the main book inventory of 1900 the population of Finland was 2712562 persons (SVT VI: 37,1$)$. The »official» resident population of Finland has been calculated at about 57000 lower or 2655900 persons (in the cities 331100 and in the countryside 2324800 persons). ${ }^{18}$

In 1901 a sub-committee collected information about the Finnish rural municipalities. Their aim was to get information concerning the position of the land-

16 We do not know whether the clergy included in the population tables all of the absent population found in the parish main books but the number of excluded persons was hardly significant.

17 There were defects already in the official figures of births. These were caused by several reasons. The parish clergy received some information about births concerning the population which was not present in the home parish - mainly of those who were still living in Finland. This information often came so late, however, that the parish clergy had already compiled the population change tables for the preceding year and thus these children were left out of the statistics. The same situation occurred with children who were born during the last months of the preceding year, but who were not baptized until after the tables were compiled (see Pitkänen 1976, 57-58 and SVT VI: $56: 1,28$ ). In addition, as late as around the year 1900 children who had died before being baptized were left out of the registers of births in some parishes, but were registered among the deaths. E.g. in the parish of Vihti this can still be seen in the 1920 's (the registers of births and deaths in the church archives of Vihti).

The figures in the official statistics concerning emigration are even more inaccurate. Considering emigration overseas the picture given by the statistics is relatively accurate (see Kero 1974, 27-47) but there was also emigration to Europe. As to return migration, even the figures concerning return from overseas are rather inaccurate. This holds true for both return migration series which exist (see Virtanen 1979, 61-67). In addition, we do not even know to what extent the migrants were - counter to the system of closed population registration - crossed off in the parish main books.

18 The "market towns», kauppalat (a municipality that was in between a city and a country village) have been grouped with the countryside for practical reasons. Nowadays, in the statistics, these towns are grouped with the cities. In 1900, however, the population of these towns was only slightly over 2000 inhabitants. 
less population, but as a by-product they also obtained a population figure for the rural municipalities in Finland. The collectors used the poll-tax registers of 1901 as their basic material and discovered that, to a large extent, the polltax registers included people who had not actually been living in the municipalities for a long time. On the other hand, the poll-tax records did not include all the population which was actually living in the municipalities. The size of the latter population was, however, much smaller than that of the former. According to the results, the population in the poll-tax records (in the beginning of 1901) was 180620 higher than the actual population in the autumn of the same year (Gebhardt 1913, 5 and 34).

The reliability of the results reached by the sub-committee has not been thoroughly evaluated afterwards. This would be very difficult, in fact, because only part of the material collected by the committee, has been preserved (see Tommila and Roiha 1976, 170-171). The sub-committee itself thought that the results somewhat underestimated the amount of the population in the countryside. They thought that this underestimation might be about $20000-30000$ persons (Gebhardt 1913, 35). This would indicate that the population of the rural municipalities would have been about 2200000 inhabitants. ${ }^{19}$ Thus the corresponding "official» resident population would be 124800 persons or 5 per cent too high.

No corresponding special investigation on which we could rely exists for the cities, but we do have the direct census taken from the largest cities in 1900 (December 5). The first census taken from the cities was not altogether successful (see e.g. SVT VI: 3,6 ), but in 1900 the reliability of the census was, undoubtedly, better. The census taken in 1900 covered only the cities of Helsinki, Turku, Tampere and Viipuri, but according to the parish main book inventory, these towns alone contained almost 60 per cent of the city population.

The population figures obtained directly from the census cannot, however, be used in this connection. To begin with, the areas included in the census also contained some of the suburbs outside the administrative boundaries of the cities (see SVT VI: 35,15 ). These areas were already taken into account by the sub-committee and are included in its figures. Secondly, the census tried to register the population which was in the city at the very time the census was taken ('de facto' population). Thus it partly included people who were only visiting the cities, while, on the other hand, it excluded those who were temporarily absent. Thirdly, the census also included people who were not Finnish citizens and were thus excluded from the parish main book inventories. Fortunately, it is possible to calculate quite accurately from the published census

19 This »corrected" figure is also meant to cover the small market towns of Finland, which were not included in the figure produced by the sub-committee. 
material the figures for Finnish citizens permanently living within the administrative boundaries of the cities. ${ }^{20}$

The population figures thus obtained were in all cases, but especially concerning Helsinki and Viipuri, clearly lower than the figures obtained from the parish main book inventory. The inventory gave a population of 200000 while the census material gave a population of 163300.21 The difference was not totally due to the absent population, because the parish main books of the cities also contained people who were actually living in the suburbs outside the city border (see SVT: 45, 57 and Jutikkala 1979, 6-7).

The population of the other cities according to the parish main book inventory was 141000 people. $^{22}$ If the trend shown by the census applies to these cities - as is probable - the figure mentioned above is too large. It is not possible to know the true amount of the population of these towns, but one must note that in towns where the census was taken, the figures obtained from the poll-tax records matched those obtained from the census very well (except for Helsinki - but the capital of Finland was in many respects a special case). The records probably included absent population as they did in the countryside, but on the other hand they probably did not include all the population which was actually living in the cities. This probably explains why these figures matched so well. If we start from the assumption that the poll-tax records give a fairly accurate picture of the population of the cities in question, we can estimate that these cities had about 127000 inhabitants. $^{23}$

By adding together the estimated population figures for the two groups of cities we get a total of 290300 for the whole city population in Finland. According to this estimate the wofficial» resident population would have been 40800 or 12 per cent too high for the cities. From the information given above we can compile the following Table:

20 Comparable figures have been calculated in the published statistics (SVT VI: 35 , 28), but this has been done somewhat erroneously, mainly because persons only temporarily staying within the cities were not subtracted from the population figures obtained nor were those who were temporarily absent added. The new figures have been calculated by the author according to the system used in 1910 (see SVT VI: 44: 8, 28-29). The difference was significant, however, only regarding Helsinki.

21 This figure also includes the population of the fortress of Viapori which was not included in the census, but on the other hand, was part of Helsinki in the parish main book inventory.

22 This figure also includes 1915 individuals who were living in the countryside of the province of Kuopio (members of the Greek-catholic parish of Joensuu). See SVT VI: 37 , table p. 72 .

23 The amount in the poll-tax records was 127066 persons but it is not altogether impossible that this figure is also too high, because the amount of the absent population may well have exceeded the number of the unregistered population in the records of the smaller cities. 
$\mathrm{Table}$ 1. The population in Finland according to the different calculations (main book inventory $=100$ ).

Population figure of

Main book inventory

Resident population

New estimates
Rural municipalities

$\begin{array}{rr}2370960 & 100 \\ 2324800 & 98 \\ 2200000 & 93\end{array}$

Cities

$341602 \quad 100$

$331100 \quad 97$

$290300 \quad 85$
The whole country

$\begin{array}{rr}2712562 & 100 \\ 2655900 & 98 \\ 2490300 & 92\end{array}$

If the new estimates presented in Table 1 give a more accurate picture of the "true" population in 1900 , it would mean that the sofficial» resident population very clearly underestimated the amount of the absent population in the parish main books. We will return to this question in the last chapter.

\section{The resident population on December 31,1910}

The population was divided into those "present» and those »absent» for the first time in the parish main book inventory of 1910 . The "official" resident population has been counted on the basis of this division (see Hyppölä et al. $1949,16)$. The difference between the total and the resident population has been calculated at almost 172000 persons (5.5 per cent of the total population). ${ }^{24}$

If the difference mentioned above tells the truth about the resident population it would make the estimate given in Table 1 concerning the resident population in 1900 questionable (over 200000 persons less than the total population), because one would expect that the amount of the sabsent» population would have grown because of the extensive emigration to America during the first decade of the 20th century. However, there are several reasons which suggest that the absent population given in 1910 may well have underestimated the true amount of the absent population.

The problem was not necessarily that the parish clergy did not know which of his parishioners were absent, although this was the case in some parishes. The poorest situation was in the large cities where the clergy was not always

24 The market towns (population of about 2300 persons) have again been grouped with the rural municipalities for practical reasons. The population figures for the cities are the following: total population 456873 and resident population 430150 (the difference, 26723 inhabitants, is about $6 \%$ of the total population). The figures for the countryside are the following: total population 2658324 and resident population 2513250 (the difference, 145074 persons, is about 5 per cent of the total population. In this division, the population "living outside the parish elsewhere in Finland" amounting to 22209 persons, has been divided between the cities and the countryside according to their proportion in the sliving within the parish population. From here on when we talk about the sresident» population, it includes those living in Finland and also including those living outside their home parishes. The spresent" population however covers only that population living in their home parishes. 
able to divide the population into the "absent» and "present» (SVT VI: 45, 9-12 and footnotes in Table II).

The situation was undoubtedly better in the countryside. The clergy still actively checked their parish main books to some extent at the general reading examinations, and especially in the smaller parishes they had rather good possibilities for closer contact with their parishioners than in the cities, for example. Thus the parish clergy had a fairly good chance of gradually discovering those who had left the parish.

I have examined the parish main books of four parishes - Kitee in eastern Finland and Vihti, Tuusula and Masku in southern Finland. It seems that the clergy of Vihti and Masku were astonishingly well aware of the movements of parishioners who were moving around in near-by parishes. The situation was not as good in Tuusula and Kitee, but at least in Tuusula the clergy seems to have gradually found out about those who had left the parish.

The clergy seems to have had greater difficulties in telling when a person had left the parish, at least the year was rather seldom entered in the main books. This was unfortunate considering the instructions given to the clergy. The clergy should have included a person among the absent population in the population table only if the individual had disappeared without leaving any trace a long time ago, or if he had left the parish at least five years earlier. The purpose of these instructions was probably that only those persons were to be included in the absent population who had been gone for such a long time that it was unlikely that he would return any more. During the period when emigration and internal migration were very active these instructions were to lead to a situation where a large number of persons who had already left the parish several years ago were included in the present population. In addition, since the clergy had difficulties in knowing when a person had actually left the parish permanently, it seems that the clergy reacted in many cases by marking as "absent» only the »certain cases», i.e., persons who had been absent for a long time during which nothing had been heard of them (see Pitkänen 1976, $284-287$ and SVT VI: $45,17-18)$.

The difficulties mentioned above clearly suggest that the size of the »absent» population obtained by the parish main book inventory well may have underestimated the true size of the "absent» population, but do we have any proof that this really was the case. The only even nearly exact figures we can get are those obtained from the direct census taken from the cities. In 1910 these cities were, however, much more numerous than ten years earlier. In December 7, 1910 a census was taken in Helsinki, Turku, Viipuri, Tampere, Nikolainkaupunki (=Vaasa), Pori and Oulu. The spresent» population of these cities made up about 70 per cent of all the "present» city population in the main book inventory.

As in 1900 the figures obtained from the census do not directly give us comparable population figures for these cities. But these figures can be calculated from the published census material (see SVT VI: 44:8, 28-29). The number 
of Finnish citizens permanently living within the administrative borders of these cities was thus $269400 .^{25}$ The size of the "present» population according to the parish main book inventory was nearly 40000 inhabitants more. As in 1900 , this difference was probably due partly to persons registered in the parish main books of the cities even though they lived outside the city limits.

What about the rest of the Finnish cities whose »present» population in the inventory was 118885 inhabitants. If the trend found in the large cities is also the same concerning the smaller cities, one would expect that this size of the "present» population is also too high. In the larger cities the figures obtained by the census matched rather well with the population amounts in the poll-tax records. It is, however, probable that because the larger cities were rapidly growing centers of industry and trade, their poll-tax records could not keep up with all those who had moved to the cities. The compatibility of the polltax amounts with the census figures was probably due to the fact that these records, on the other hand, also included a great deal of absent population. ${ }^{26}$

We do not know whether these two groups have counterbalanced each other in the poll-tax records of the smaller cities. On the contrary, it is possible that the poll-tax figures are too high. There is, however, no better estimate for the population of these cities and therefore we are forced to use the figure obtained from the poll-tax records or 113800 inhabitants, which is only 5000 persons less than the size of the spresent" population in the parish main book inventory. The result thus obtained is that the whole city population in Finland in 1910 was about 383200 inhabitants. This is about $47000(11 \%)$ inhabitants less than the »official» resident population figure.

For the countryside we cannot obtain any figures concerning the possible overestimation of the wofficial" resident population. However, the other population registers - poll-tax records - are worth a closer examination. Table 2 shows the central figures obtained from the poll-tax records and the parish main book inventory.

The difference between the total populations is natural, ${ }^{27}$ because people were much more easily excluded from the poll-tax records than from the parish main books. ${ }^{28}$ Nonetheless, the poll-tax registers contained a large amount of

25 This figure also includes the population of the fortress of Viapori.

26 One can calculate the amount of the present population also in the poll-tax records, because the absent population was separated in them. The amounts of "present" population in most cities were considerably lower than the figures obtained from the census material.

27 The total population in the poll-tax records differs slightly from the figure presented in the official statistics (SVT VI: 45, Table II) due to the erroneous figure for the municipality of Sulva in the statistics.

28 This can already be seen when one compares population growth in 1900-1910 in the parish main book inventories and in the poll-tax records. The growth was almost 70000 persons higher in the inventories than in the poll-tax records. 
Table 2. Population figures for the countryside in the parish main book inventory (31.12.1910) and in the poll-tax records (1.1.1911).

$\begin{array}{llccc} & \begin{array}{c}\text { Total } \\ \text { population }\end{array} & \begin{array}{c}\text { Present } \\ \text { population }\end{array} & \begin{array}{c}\text { Resident } \\ \text { population }\end{array} \\ 1 \text { The parish main book inventory } & 2658300 & 2494300 & 2513250 \\ 2 \text { The poll-tax records } & 2593900 & 2468500 & \ldots \\ 3 \text { The difference between row 1 and 2 } & 64400 & 25800 & \text {. }\end{array}$

Sources: SVT VI: 45, 22-23 and Tables I and XIII. Poll-tax records in the National Archives of Finland.

absent population. From 1903 onwards the poll-tax records had a column in which the registrars of the rural jurisdictional districts (kihlakunnan henkikirjoittajat) had to note if a person was absent. In 1911 the size of the absent population was about 125000 persons and this figure was so much smaller than the corresponding figure in the parish main book inventory that the amount of the present population was only slightly smaller in the poll-tax records. At first sight the small difference between the figures would seem to support the results obtained in the parish main book inventory concerning the amount of the present population in the countryside.

When examining the poll-tax records more closely, one must, however, conclude that these records have clearly overestimated the amount of the present population in them. This again suggests that also the parish main book inventory has overestimated the size of the present population.

In 1908 the Central Statistical Office of Finland sent a questionnaire to the district registrars responsible for compiling poll-tax records. In this questionnaire the Office asked, e.g., what grounds were used when a person was entered in the column of the absent population. One can see from the answers ${ }^{29}$ that there was a certain time lapse before a person was moved into the column for absent persons. Usually this seems to have been a year or two, but longer time lapses were also mentioned. In addition, one can see that the concept of an »absent person» was understood in different ways by different registrars. Often an absent person was any person who had stayed outside the municipality for a longer period of time. Just as often absent persons were determined in such a way that only a part of those living outside the municipality were marked in the column. In several cases only those who had emigrated were considered as sabsent» and sometimes not even all of them. There were numerous variations.

In many cases the registrars emphasized that they put a person in the column for the absent only if they were certain that he or she had been gone for a

29 The answers are in the Archives of the Central Statistical Office, the out-going mail in 1908 and the in-coming mail in 1909. 
longer time. The dilemma in this is that the registrars had great difficulties in getting sufficient information concerning the population in their district. They should have gotten the information as "first hand" information at the registration occasion from the population itself. There were, however, relatively few who actually came in person to this occasion.

It has been emphasized that the district registrars based their information on the parish books, which were to be used in assistance at the registration occasion (see Väestötilastokomitean mietintö 1923: 7, 24-25). It is more probable, however, that the basis for a new poll-tax record was the old record and that the parish main books were used only to a very limited extent. Otherwise it would be very difficult to explain the differences between the information given by the poll-tax records and the parish main books. ${ }^{30}$

The situation described above undoubtedly caused the registrars to fail to register all the people in the poll-tax records. However, the opposite effect has, no doubt, been much more significant in the countryside, which lost rather than gained from the migration movement. It must have been very difficult for the registrars to find out about all persons no longer staying in their district.

The difficulties described above can also be seen directly in the poll-tax registers of 1911. In many districts only those persons who were on the passport lists of the Finnish Passport Office in St. Petersburg were marked as »absent». In many districts the number of vagrants (irtolainen, löysä) was large, but in some cases they were all marked as present or only those who were mentioned as staying abroad were marked as "absent».31 A large part of these people probably were not present, as most of the registrars mentioned in their answers to the Central Statistical Office, but the registrars seemed to have preferred to mark a person »absent» only if they were sure of it.

I have divided the rural jurisdictional districts into two groups. In the first group I have included those districts in which it seemed that the registrar had not even tried to find out who were absent and in the second group the other districts. This division was made mainly with the help of examining the records themselves, but the answers of the registrars to the Central Statistical Office in 1908-1909 were also used in assistance. The division is naturally subjective, but the results were interesting. Table 3 presents the population

30 I compared the information concerning the absent population obtained from the parish main books of Vihti and Tuusula and found out that part of this absent population around the year 1910 were marked as present in the poll-tax registers of 1911 (see also Pitkänen 1976, 275-278).

31 In most of these cases the size of the present population was much larger in the poll-tax records than in the parish main book inventory. This was not, however, always the case. E.g. in the district of Kymi in the province of Viipuri there were only a few persons marked as staying in Russia or America, but the size of the present population in the poll-tax records was significantly smaller than in the parish main book inventory. Because the size of the vagrant population was relatively small the absent population was probably left out of the poll-tax records to a great extent. 
figures for the second group of districts (by provinces), in which it seemed that the registrars had tried to find out the absent population.

In this sample the present population is much smaller in the poll-tax records than in the parish main book inventory. The differences between the provinces were, however, very large, but these differences seem plausible in many cases.

T a ble 3. Sample of the poll-tax records (1911) in comparison with the parish main book inventory (1910), by provinces.

$\begin{array}{lcccc}\text { Province } & \begin{array}{c}\text { Total } \\ \text { population } \\ \text { in poll-tax } \\ \text { records }\end{array} & \begin{array}{c}\text { Present } \\ \text { population } \\ \text { in poll-tax } \\ \text { records }\end{array} & \begin{array}{c}\text { Present } \\ \text { population } \\ \text { in main book } \\ \text { inventory }\end{array} & \begin{array}{c}\text { "Resident» } \\ \text { population } \\ \text { in poll-tax } \\ \text { records }\end{array} \\ \text { Uusimaa } & 109203 & 105259 & 106071 & 107817 \\ \text { Turku and Pori } & 107938 & 102872 & 104618 & 103378 \\ \text { Häme } & 63083 & 60769 & 63217 & 62597 \\ \text { Vaasa } & 306436 & 270484 & 270484 & 286506 \\ \text { Viipuri } & 303338 & 295291 & 312569 & 297339 \\ \text { Mikkeli } & 89345 & 84863 & 86658 & 87577 \\ \text { Kuopio } & 312599 & 291171 & 303455 & 307352 \\ \text { Oulu } & 255240 & 244600 & 255761 & 246041 \\ \text { Total } & 1547182 & 1455309 & 1502833 & 1498607\end{array}$

Sources: Poll-tax records of 1911 in the National Archives of Finland and SVT VI: 45, Table II.

Sample rural jurisdictional districts are the following. Uusimaa: districts of Lohja and Pernaja; Turku and Pori: districts of Ikaalinen and Loimaa; Häme: district of Tammela; Vaasa: districts of Ilmajoki, Kuortane, Lapua and Pietarsaari; Viipuri: districts of Kurkijoki, Kymi, Käkisalmi, Lappee, Ranta and Sortavala; Mikkeli: districts of Heinola and Mikkeli. Kuopio: all districts; Oulu: all districts except for the district of Lappi.

The present population was significantly lower in the poll-tax records than in the main book inventory in many provinces from which there was a considerable migration flow (e.g., province of Viipuri, Kuopio and Oulu). On the other hand, the difference between the poll-tax records and the parish main book inventory was small in the province of Uusimaa, in which there were several industrial centers in the countryside and populous suburbs of Helsinki outside the city limits. ${ }^{32}$ Thus the sample, in spite of its many weaknesses, seems to reflect to some extent the changing regional composition of the population.

Table 3 naturally can give only a very vague idea of the amount of overrepresentation of the "present" population in the parish main book inventory,

32 In many cases the poll-tax records of those rural municipalities which were adjacent to large cities included a significantly larger population than did the parish main books. 
although it clearly suggests that such over-representation exists. First of all, the districts included in the Table do not form a representative sample of the Finnish districts. Secondly, it is most probable that even in these districts the registrars failed to find out all of the absent population. This is most apparent in the province of Vaasa.

One must also bear in mind that these figures of the spresent» population also contain people living within Finland, although they were staying outside their home municipality or parish. Taking into consideration the entire Finnish countryside their size in the parish main book inventory was rather small, only 19000 or 12 per cent of the total amount of the absent population (SVT VI: 45, Table XIII). No comparable figure can be obtained for the poll-tax records. As can be calculated from Table 3 only about one half of the absent population in the sample had a mark indicating that the individual was staying abroad and thus the "resident» population in the poll-tax records was almost as large as the amount of the present population in the parish main book inventory. Most of the other absent persons in the poll-tax records had only an »absent» mark or "place of residence unknown", but it is probable that a very large part of this population actually had moved abroad. ${ }^{33}$

Because of all the factors mentioned it is not fruitful to begin guessing at the amount of over-representation in the wofficial» figure of resident population concerning the countryside. This figure is based in practice on the size of the present population given by the main book inventory. Because the sample in Table 3 clearly shows that the present population in the main book inventory is probably much too large, this suggests that the over-representation in the size of the resident population of the countryside is also not insignificant. It is probably a question of several tens of thousands of persons. When also considering the cities, it is possible that the "official» resident population of Finland exaggerates the true population of Finland by much over 100000 persons.

\section{Discussion}

In the previous chapters I have tried to show how the system of population registration affected unfavorably the reliability of the Finnish population statistics at the turn of the century. It also seems that it has not even been fully understood how large the deviations from the strue» figures may have been.

It must be emphasized that all the estimates given above are more or less crude. E.g., concerning the resident population in the Finnish countryside in

3s In several districts there was no indication in the poll-tax records of knowledge of an individual's whereabouts except for those who were staying on a passport in Russia (in the entire countryside about 15000 persons). 
1910 it has only been possible to bring forth some data which indicate that the actual «resident» population may have been significantly lower than the »official» figure. But it is obvious that we cannot blindly trust even the censuses of the cities or the figure produced by the sub-committee.

Therefore the estimates have not been given with the intention that corrections be made with them as a basis. They merely indicate certain reliability limits, which the researcher must take into account when he draws conclusions from the data based on the population statistics. More difficulties arise because of the fact that the total population figures alone are seldom sufficient, instead it is necessary to use figures concerning different age, occupational, etc. groups or different regions. This can all be rather annoying to researchers who are accustomed to drawing conclusions from relatively small changes in the figures. But if one is not ready to accept the rather wide limits of unreliability and a certain amount of uncertainty, the historical data are not for him.

\section{References}

Engman, Max, Den kyrkliga registeringen av finländare i Ryssland. Genos 1976:4 (Engman 1976).

Engman, Max, Migration from Finland to Russia during the Nineteenth Century. Scandinavian Journal of History, Vol. 3, 1978: 2 (Engman 1978).

Engman, Max, Flyttning och medborgarskap. Passlagstiftningen för finländare i Ryssland 1809-1917. Historisk Tidskrift för Finland 1978: 1 (Engman 1978 a).

Gebhardt, Hannes, Jordbruksbefolkningen, dess förhållande till andra yrkesgrupper och dess sociala sammansättning. Subkomitén för den obesuttna befolkningen. Statistisk undersökning af socialekonomiska förhållanden i Finlands landskommuner år 1901. Helsingfors 1913 (Gebhardt 1913).

Hjelt, August, Det Svenska tabellverkets uppkomst, organisation och tidigare verksamhet. Helsingfors 1900 (Hjelt 1900).

Hjerppe, Riitta and Pihkala, Erkki, The Gross Domestic Product of Finland. Economy and History, Vol. XX: 2, 1977 (Hjerppe and Pihkala 1977).

Hornborg, A. J., Sammandrag af Domkapitlets i Borgå härförinnan otryckta Circulärbref (1725-1829) i alfabetisk och kronologisk följd utarbetadt. Borgå 1872 (Hornborg 1872).

Hyppölä, Jorma, Tunkelo, Aarre and Törnqvist, Leo, Suomen väestöä, sen uusiutumista ja tulevaa kehitystä koskevia laskelmia. Tilastollisia tiedonantoja, julk. Tilastollinen päätoimisto. 38. Helsinki 1949 (Hyppölä et al. 1949).

Jutikkala, Eino, Tampereen historia 3. Tampere 1979 (Jutikkala 1979).

Kero, Reino, Migration from Finland to North America in the Years between the United States Civil War and the First World War. Annales universitatis Turkuensis, ser. B: 130. Turku 1974 (Kero 1974).

Lempiäinen, Pentti, Kastekäytäntö Suomen kirkossa 1500- ja 1600-luvulla. Suomen Kirkkohistoriallisen Seuran toim. 69. Forssa 1965 (Lempiäinen 1965).

Lundell, Oscar, Bidrag till den Finska befolkningsstatistikens historia. Helsingfors 1913 (Lundell 1913).

Pitkänen, Kari, Ongelmia olemattomuudesta - Väestöä ja väestönmuutoksia kuvaavien lähteiden luotettavuudesta ja käyttökelpoisuudesta lähinnä Kiteen ja Rääkkylän 
seurakuntien aineiston perusteella v. 1722-1877. A study for the Licentiate degree in Finnish history, University of Helsinki, Department of History, 1976, unpublished (Pitkänen 1976).

Pitkänen, Kari, Stad och influensområde. Flyttningsrörelse och social förändring före industrialiseringsperioden (ca 1720-1850). A paper presented at the third Nordic symposium for local history in Gaasdal, Norway, 6-9 August, 1979.

Rosenberg, Antti, Väestön maantieteellisestä liikkuvuudesta Suomessa 1700-luvulla. Historiallinen Aikakauskirja 1967: 3 (Rosenberg 1967).

Soininen, Arvo, Vanha maataloutemme. Maatalous ja maatalousväestö Suomessa perinnäisen maatalouden loppukaudella 1720-luvulta 1870-luvulle. Hist. Tutk. 96, published by Suomen Historiallinen Seura. Helsinki 1974 (Soininen 1974).

Suomen virallinen tilasto, Official Statistics of Finland (SVT). Väestötilasto, Population Statistics (VI). The arabic number refers to the volume number.

Talas, Onni, Kotipaikka-oikeus Suomen lain mukaan. Helsingissä 1905 (Talas 1905).

Tommila, Päiviö and Roiha, Juhani, Sosiaalihistoria ja sen tutkimus. Turun yliopisto, historian laitos, Suomen historia, julk. No 2. Turku 1976 (Tommila and Roiha 1976). Virtanen, Keijo, Settlement or Return. Finnish Emigrants (1860-1930) in the International Overseas Return Migration Movement. Studia Historica 10, published by the Finnish Historical Society. Helsinki 1979 (Virtanen 1979).

Väestötilastokomitean mietintö n:o 1. 1923:7. Helsinki 1923 (Väestötilastokomitean mietintö 1923: 7). 